\title{
Pengadaan Bahan Pustaka Dinas Perpustakaan Dan Arsip Daerah Kabupaten Muaro Jambi
}

\author{
Wiwin Irpina \\ IIS-Kosentrasi Ilmu Perpustakaan dan Informasi, UIN Sunan Kalijaga Yogyakarta \\ Jl. Laksda Adisucipto, Daerah Istimewa Yogyakarta 55281 \\ Email: wiwinirpina29@gmail.com
}

\begin{abstract}
This study aims to determine the process of procurement of library materials at the Regional Library and Archives Service of Muaro Jambi Regency. The research method used is library research methodologically classified as qualitative research with a descriptive approach in the form of a case study which aims to explain the procurement of library materials at the Regional Library and Archives Service of Muaro Jambi Regency. Data collection techniques used were through observation and interviews. The findings of the study are (1) the Regional Library and Archives Office of Muaro Jambi Regency has carried out library material procurement activities through purchases from book agents, bookstores, gifts, entrances and through assistance once a year. (2) The Regional Library and Archives Office of Muaro Jambi Regency has never procured serial publications, as well as non-book materials (recorded works) because according to them library materials are rarely needed by users. (3) The procurement of library funds for library materials is not running properly as seen from the constraints that occur, namely the lack of spending funds for the procurement of library materials both from series published library materials and recorded library materials, as well as the lack of attention from leaders leading to the procurement of library materials so that the available collections incomplete, not up to date and not used by the user. From these findings, it is hoped that the Regional Library and Archives Office of Muaro Jambi Regency will continue to procure collections of serial publications and recorded works because these collections can increase the number of collections available, create public interest in reading and add to the repertoire of library collections. Furthermore, the Regional Library and Archives Service of Muaro Jambi Regency should process funds properly by paying attention to user needs so that library materials purchased are in accordance with user education. Then also the head of the library must pay more attention that leads to the procurement of library materials so that the available collections can be more up to date, complete, and can be used by users.
\end{abstract}

\section{Keywords: Library Material Procurement, Library Collection, Public Library}

\begin{abstract}
ABSTRAK
Penelitian ini bertujuan untuk mengetahui proses pengadaan bahan pustaka Dinas Perpustakaan dan Arsip Daerah Kabupaten Muaro Jambi. Metode penelitian yang digunakan adalah kepustakaan (Library Research) secara metodelogis tergolong kepada jenis penelitian kualitatif dengan pendekatan deskriptif berupa studi kasus yang bertujuan menjelaskan pengadaan bahan pustaka di Dinas Perpustakaan dan Arsip Daerah Kabupaten Muaro Jambi. Teknik pengumpulan data yang digunakan yakni melalui observasi dan wawancara. Temuan penelitian yaitu (1) Dinas Perpustakaan dan Arsip Daerah Kabupaten Muaro Jambi telah melakukan kegiatan Pengadaan bahan pustaka melalui pembelian dari agen buku, toko buku,
\end{abstract}


hadiah, titipan dan melalui bantuan sebanyak 1 kali setiap tahunnya. (2) Dinas Perpustakaan dan Arsip Daerah Kabupaten Muaro Jambi tidak pernah melakukan pengadaan terbitan berseri, serta bahan non buku (karya rekam) karena menurut mereka bahan pustaka tersebut jarang dibutuhkan oleh pemustaka. (3) Pengadaan dana perpustakaan bahan pustaka tidak berjalan dengan benar terlihat dari kendala yang terjadi yakni kurangnya dana belanja untuk pengadaan bahan pustaka baik dari bahan pustaka terbitan berseri maupun bahan pustaka terekam, serta kurangnya perhatian pemimpin yang mengarah pada pengadaan bahan pustaka sehingga koleksi yang tersedia tidak lengkap, tidak up to date dan tidak terpakai oleh pemustaka. Dari temuan tersebut diharapkan Dinas Perpustakaan dan Arsip Daerah Kabupaten Muaro Jambi tetap malakukan pengadaan koleksi terbitan berseri maupun karya rekam karena dengan koleksi tersebut bisa menambah jumalah koleksi yang tersedia, mewujudkan minat baca masyarakat serta menambah khasanah koleksi perpustakaan. Selanjutnya Dinas Perpustakaan dan Arsip Daerah Kabupaten Muaro Jambi sebaiknya harus mengolah dana dengan baik dengan memperhatikan kebutuhan-kebutuhan pengguna agar bahan pustaka yang di beli sesuai dengan user education. Kemudian juga kepala perpustakaan harus memberikan perhatian lebih yang mengarah pada pengadaan bahan pustaka sehingga koleksi yang tersedia nantinya bisa lebih up to date, lengkap, dan bisa terpakai oleh pemustaka.

\section{Kata Kunci: Pengadaan Bahan Pustaka, Koleksi Perpustakaan, Perpustakaan Umum.}

\section{A. PENDAhuluan}

Keberadaan bahan pustaka dalam sebuah lembaga informasi (Perpustakaan) mempunyai peranan yang sangat penting, bahkan cukup menentukan keberhasilan penyelengaraan suatu perpustakaan. ${ }^{1}$ Bahan pustaka tidak terpaku pada buku saja namun melingkupi segala jenis dan bentuk koleksi yang terekam dan tercetak seperti majalah, koran surat kabar, lukisan pamphlet, kaset, microfilm, slide, piringan hitam dan lainnya. ${ }^{2}$ Dapat disimpulkan bahwa bahan pustaka adalah semua koleksi yang terkumpul di perpustakaan dan berguna untuk memenuhi kebutuhan informasi bagi pemustaka. Dimana perpustakaan sebagai pengolah informasi, dituntut untuk mampu memfasilitasi dan menyediakan berbagai bentuk bahan pustaka. Agar bahan pustaka perpustakaan tepat guna, dimanfaatkan secara maksimal tidak hanya sebatas pajangan belaka karena banyak koleksi perpustakaan tidak terpakai atau memenuhi kebutuhan informasi pengguna, maka pengelola perpustakaan perlu melakukan perencanaan untuk mengembangkan bahan pustaka yang dimilki dengan pertimbangan tertentu. Mingsalnya relevansi, kemukhtahiran, kualitas maupun kuantitas dan sesuai dengan objek keilmuan serta kriteria atau jenis bahan pustaka perpustakaan menentukan jenis perpustakaan. ${ }^{3}$

${ }^{1}$ Elva Rahmah, Testiani Makmur, Kebijakan Sumber Informasi Perpustakaan:Teori Dan Aplikasi (Yogyakarta:Graha Ilmu, 2015), 1.

${ }^{2}$ Sulistyo Basuki, Pengantar Ilmu Perpustakaan. (Jakarta: PT. Gramedia Pustaka Utama, 1993), 16.

${ }^{3}$ Elva Rahmah, Testiani Makmur, Kebijakan Sumber Informasi Perpustakaan:Teori Dan Aplikasi. 2. 
Pengadaan bahan pustaka merupakan rangkaian kebijakan pengembangan koleksi sebuah perpustakaan. Semua kebijakan pengembangan koleksi akhirnya bermuara pada pengadaan bahan pustaka. Koleksi yang menjadi prioritas utama pengadaan sudah di tentukan dalam kebijakan pengembangan koleksi. ${ }^{4}$ Pengadaan bahan pustaka merupakan suatu proses penghimpun bahan pustaka yang dimiliki setiap perpustakaan yang akan membentuk sebuah koleksi. Bahan pustaka yang diadakan oleh sebuah perpustakaan hendaknya harus sesuai dengan kebutuhan, lengkap, minat pemustaka dan terbitan mukhtahir. Agar tidak mengabaikan kebutuhan informasi masyarakat atau pemustaka yang akan dilayani, koleksi perpustakaan berasal dari berbagai macam sumber seperti hadiah, pembelian, tukar menukar, titipan dan terbitan sendiri. ${ }^{5}$ Pengadaan koleksi atau bahan pustaka di sebuah perpustakaan sangat berpengaruh dalam meningkatkan mutu atau kualitas suatu perpustakaan karena diharapkan mampu menyajikan informasi yang cari pengguna secara cepat, tepat dan akurat. Suatu perencanaan pengadaan bahan pustaka merupakan suatu proses berfikir untuk menentukan usaha atau langkah yang akan dilakukan pada masa yang akan datang guna memperoleh bahan pustaka (koleksi) dalam rangka terwujudnya sebuah perpustakaan dengan sebaik-baiknya. ${ }^{6}$

Ada beberapa bentuk pengadaan bahan pustaka yang bisa dilakukan yaitu pengadaan melalui pembelian, hadiah, dan pertukaran. Bahan pustaka yang akan diadakan mengcakup (1) karya cetak atau karya grafis, seperti buku, majalah, surat kabar, disertasi, dan laporan; (2) karya non-cetak atau karya rekam, seperti piringan hitam, kaset, dan video; (3) bentuk micro, seperti microfilm, dan microfis; (4) karya elektronik, seperti disket, pita magnetic, serta selongsong, elektronik yang diasosiasikan dengan komputer. Pengadaan atau akuisisi dilakukan oleh bagian pengdaan. ${ }^{7}$

Selanjutnya tujuan dari pengadaan bahan pustaka agar koleksi sesuai dengan kebutuhan pengguna. Kesesuaian diharapkan dapat meningkatkan pemanfaatan koleksi perpustakaan. Koleksi perpustakaan harus terbina dari suatu koleksi yang sistematis dan terarah disesuaikan dengan tujuan, rencana, anggaran yang tersedia. Dengan adanya pengadaan bahan pustaka maka koleksi perpustakaan dapat dibina sebaik mungkin sehingga tujuan perpustakaan dapat tercapai.

\footnotetext{
${ }^{4}$ Darmono, Perpustakaan Sekolah:Pendekarab Aspek Manajemen dan Tata Kerja. (Jakarta: Grasindo, 2007), 9.

${ }^{5}$ Soetimah, Perpustakaan Pustakawan Dan Kepustakawanan, (Yoogyakarta:Kanisius, 1992) Hlm. 15

${ }^{6}$ Gusnimar, Delman. Pengadaan Bahan Pustaka Di Perpustakaan Politeknik Pertanian Universitas Andalas Payakumbuh. Jurnal Ilmu Informasi Perpustakaan dan Kearsipan Vol. 1, No. 1, September2012, Seri B. 133.

${ }^{7}$ Elva Rahmah, Testiani Makmur, Kebijakan Sumber Informasi Perpustakaan:Teori Dan Aplikasi. 84.
} 
Dinas Perpustakaan dan Arsip Daerah Kabupaten Muaro Jambi berdiri dari 2017 hingga sekarang tahun 2020 mereka telah melakukan pengadaan setiap 1 tahun 1 kali jadi total pengadaan yang telah dilakukan selama ini sebanyak 3 kali pengadaan bahan pustaka tercetak. Perpustakaan selalu berusaha memberikan layanan prima kepada pemustaka yang terdiri dari siswa, peneliti, mahasiswa dan masyarakat Kabupaten Muaro Jambi. salah satu wujud nyata adalah menyediakan beragam koleksi penunjang untuk para pemustaka yang hingga saat ini berjumlah 9.153 eksemplar. Selain itu, cara untuk meningkatkan kualitas perpustakaan dan mencapai pelayanan prima adalah dengan melaksanakan pengadaan bahan pustaka perpustakaan. Melalui pengadaan bahan pustaka ini, Dinas Perpustakaan dan Arsip Daerah (DPAD) Kabupaten Muaro Jambi dapat meningkatkan jumlah koleksi serta mampu mengetahui apa saja koleksi yang dibutuhkan oleh para pemustaka. Namun, hingga saat ini koleksi yang tersedia semua dalam bentuk koleksi cetak, dan belum ada sama sekali koleksi terbitan berseri serta belum tersedia koleksi elektronik (non buku).

Berdasarkan permasalah diatas, artikel ini akan terfokus pada proses pengadaan bahan pustaka Dinas Perpustakaan dan Arsip Daerah Kabupaten Muaro Jambi. Artikel ini akan menjelaskan kegiatan atau langkah-langkah yang dilakukan oleh pengelola perpustakaan dalam melaksanakan kegiatan pengadaan bahan pustaka. Di dalam artikel ini juga menjelaskan hambatan yang terjadi dalam proses pengadaan bahan pustaka. Sehingga kedepannya pengelola Dinas Perpustakaan Dan Arsip Daerah Kabupaten Muaro Jambi dapat menyiapkan rencana dengan matang agar pengadaan koleksi di perpustakaan dapat berjalan dengan lancar.

\section{B. METODE PENELITIAN}

Metode Penelitian merupakan cara ilmiah untuk mendapatkan data dengan tujuan dan kegunaan tertentu. Metode penelitian merupakan cara yang digunakan seorang peneliti dalam mengumpulkan data penelitiannya. ${ }^{8}$ Penelitian ini menggunakan jenis penelitian kepustakaan (Library Research) yang secara metodelogis tergolong kepada jenis penelitian kualitatif karena penelitian kualitatif akan menghasilkan data berupa ucapan, tulisan, atau perilaku dari orang atau objek yang diamati menggunakan suatu konteks tertentu, dibahas dari sudut pandang yang utuh, kompherensif dan holistik. Dalam penelitian kepustakaan, data-data yang diambil dari eksplorasi penelitia terhadapat koleksi-koleksi yang memuat

\footnotetext{
${ }^{8}$ Sugiyono, Metode Penelitian Kuantitatif, Kualitatif $R \& D$ (Bandung:Elfabeta, 2007), 3.
} 
data tersebut. Kemudian akan dikaji secara holisttik, dianalisis menggunakan teori tertentu dan menggunakan pendekatan tertentu untuk mencapai tujuan penelitian yang diinginkan. ${ }^{9}$ Adapun metode pengumpulan data dilakukan melalui:

1. Obserervasi atau pengamatan

Observasi merupakan cara atau langkah yang diambil peneliti untuk mengumpulkan data guna mengetahui pengadaan bahan pustaka Dinas Perpustakaan dan Arsip Daerah Kabupaten Muaro Jambi.

2. Wawancara atau Interview

Wawancara adalah teknik pengumpulan data yang digunakan peneliti untuk mendapatkan keterangan-keterangan lisan melalui percakapan dan berhadapan muka dengan pengelola perpustakaan mematuhi protocol kesehatan Covid-19, pengelola di anggat dapat memberikan keterangan atau informasi pada peneliti, wawancara ini dilakukan untuk melengkapi data yang diperoleh.

\section{KAJIAN TEORI}

\section{Pengadaan Buku Melalui Pembelian}

Perpustakaan dalam memperoleh bahan pustaka dapat dilakukan dengan cara-cara pemesanan langsung. Pemesanan dapat dilakukan pada penerbit ataupuntoko buku. Penerbit Indonesia pada umumnya melayani permintaan perpustakaan. Akan tetapi penerbit asing umumnya tidak melayani permintaan perpustakaan. Penerbit asing hanya melayani pembelian dari took buku atau penjaja (vendor) sehingga perpustakaan Indonesia harus membeli melalui took buku. Proses pemesanan dapat melalui took buku, memesan langsung kepenerbit, agen, dan mengimpor langsung dari luar negeri (penerbit luar negeri). ${ }^{10}$

\section{a. Toko Buku}

Pembelian bahan pustaka langsng ke took buku banyak dilakukan oleh perpustakaan yang jumlah dananya relative sedikit. Pembelian dengan cara ini biasanya dilakukan untuk judul dan eksemplar yang tidak banyak. Kekurangan yang umumnya terjadi pada pembelian bahan pustaka ke took buku adalah tidak semua subjek atau judul yang dibutuhkan perpustakaan tersedia di toko buku, took buku tidak selalu bisa ditemukan di setiap kabupaten sehingga tidak mampu melayani kebutuhan perpustakaan, took buku yang terdapat di kota kecil pada

\footnotetext{
${ }^{9}$ Amir Hamzah. Metode Penelitian Kepustakaan (Library Research). (Malang:Literasi Nusantara Abadi, 2019), 25.

${ }^{10}$ Elva Rahmah, Testiani Makmur, Kebijakan Sumber Informasi Perpustakaan:Teori Dan Aplikasi. 86.
} 
umumnya hanya menyediakan bahan pustaka yang berbahasa Indonesia dan tidak semua pesanan bahan pustaka dari satu perpustakaan dapat dipenuhin dari satu took buku saja.

\section{b. Penerbit}

Pembelian bahan pustaka juga dapat dilakukan melalui penerbit, pemesanan secara langsung ke penerbit dapat dilakukan apabila judul-judul yang dibutuhkan betulbetul diterbitkan oleh penerbit tersebut. Untuk mengetahui hal tersebut perpustakaan dapat memanfaatkan katalog penerbit yang dikeluarkanpenerbit sehingga bahan pustaka yang akan diadakan dapat dipesan langsung pada penerbitnya.

\section{c. Agen Buku}

Selain pembelian ke toko buku dan penerbit, perpustakaan juga dapat membeli buku melalui agan yang biasa disebut dengan Jobber atau Vendor. Agen buku ini berperan sebagai mediator antara perpustakaan dan penerbit, terutama untuk pengadaan bahan pustaka terbitan luar negeri. Untuk negara berkembang, seperti Indonesia, persoalan yang dihadapi adalam pengadaan buku jauh lebih rumit dari pada negara maju. Persoalan yang dihadapi pustakawan Indonesia dalam hal ini pengadaam buku, diantaranya terbitan dalam negeri, prosedur pembayarannya, ketersediaan dana, katalog penerbit, administrasi dan sensor. Berikut ini beberapa pertimbangan yang harus diperhatikan dalam pemesanan buku yaitu;

a) Pemesanan buku harus mengikuti dana atau anggaran yang ada

b) Memesan buku harus berdasarkan pertimbangan atas kegunaan bahan pustaka bagi pemustaka

c) Pemesanan buku berdasarkan pada seleksi yang sudah dilakukan

d) Dalam memesan bahan pustaka perlu dipertimbangkan pengarang, judul, penerbit, tahun terbit, edisi, harga, subyek, jumlah pesanan, serta kegunaan

e) Pemesanan buku harus mengikuti langkah berikut ini; membuat surat pesanan lalu diketik 3 rangkap (guna untuk dikirimkan kepada penerbit ataupun toko buku, arsip, dan ditempel di papan pengumuman perpustakaan untuk diketahui oleh pengguna), pesanan disertai price, pesanan harus disertakan surat pengantar dari pemesan. 


\section{PESANAN BUKU}

Nama Perpustakaan :

Kepala Perpustakaan :

Alamat Perpustakaan :

No. Nama Pengarang Judul Penerbit Edisi Jumlah Harga Satuan Harga Total

Keterangan

Mengetahui

Direktur Kantor

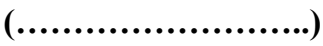

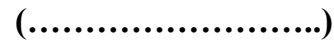

Gambar 1.1 Contoh Blangko Pemesanan Buku

Prosedur kerja pemesanan buku dan monograf lainnya meliputi kegiatankegiatan yatu (a) mengirim daftar pesanan ke agen atau pemasok buku atau took buku (b) menerima profarma invoice (c) mencocokkan profarma invoice dengan daftar pesanan (d) memeriksa alokasi dana (e) menyetujui untuk di beli (f) memberitahu bagian keuangan untuk melakukan pembayaran.

\section{Pengadaan Buku Melalui Hadiah}

Bahan pustaka yang diperoleh melalui hadiah sangat penting untuk menambah koleksi perpustakaan. Perpustakaan yang menerima bahan pustaka berupa hadiah dapat menghemat biaya pembelian. Hadiah buku bisa didapatkan dari berbagai sumber baik dari instansi pemerintahan, swasta maupun pribadi. Sumber yang bisa diharapkan untuk bisa menyumbang buku diantaranya adalah pengarang dan penerbit sebagai contoh terbitannya, duplikat terbitan dari perpustakaan lain, instansi pemerintah sebagai terbitan pemerintah, dan donator dari berbagai pihak seperti organisasi, lembaga perhimpunan profesi, yayasan, negara maju melalui kedutaan. Ada beberapa cara mendapatkan hadiah, yaitu hadiah atas permintaan dan hadiah tidak atas permintaan. ${ }^{11}$

a. Hadiah atas permintaan

${ }^{11}$ Elva Rahmah, Testiani Makmur, Kebijakan Sumber Informasi Perpustakaan:Teori Dan Aplikasi. 91. 
Prosedur perolehan hadiah atas permintaan yaitu mempersiapkan daftar donator yang akan diminta sumbangannya. Pustakawan menyusun daftar bahan pustaka yang akan diajukan kepada pihak lain, baik dalam negeri maupun luar negeri. Daftar permohonan akan dikirimkan kepada alamat yang dituju disertai surat pengantar. Apabila pihak donor telah mengirimkannya, petugas memeriksa kiriman tersebut dan dicocokkan dengan surat pengantarnya dan mengirimkan ucapan terimakasih. Selanjutnya bahan pustaka di proses seperti biasa, yaitu inventarisasi dan seterusnya.

b. Hadiah tidak atas permintaan

Prosedur perolehan hadiah tidak atas permintaan yaitu bahan pustaka yang diterima dicocokkan dengan surat pengantar; perpustakaan menulis surat ucapan terimakasih. Bahan pustaka yang diterima ditelusuri dulu apakah subjeknya sesuai dengan tujuan perpustakaan, apakah tidak diplikat. Jika bahan pustaka benar-benar telah sesuai dengan segera diproses. Jika bahan pustaka tidak sesuai, disisihkan sebagai bahan pertukaran atau dihadiahkan pada perpustakaan lain yang bahan pustaka itu sesuai dengan penggunanya.

\section{Pengadaan Buku Melalui Tukar Menukar}

Tukar menukar ini bisa dilakukan bila perpustakaan mempunyai buku yang dianggap tidak sesuai dengan tujuan perpustakaan yang dikelola atau dianggap jumlah eksemplar tiap judul lebih, maka buku tersebut dapat ditawarkan kepada perpustakaan lain untuk ditukarkan dengan buku-buku yang dikehendaki pihak perpustakan yang menawarkan. ${ }^{12}$

\section{Pengadaan Buku Melalui Titipan}

Penambahan buku dapat juga diperoleh dengan cara titipan atau pinjaman sementara dari perpustakaan lain. Dalam melakukan titipan buku diharuskan dalam jangka waktu lama alasannya karena jika waktunya terlalu singkat akan merugikan perpustakaan bersangkutan yang telah menerima titipan, dan juga besarnya biaya (administrasi) sebagai proses buku yang telah dititipkan menurut sistem perpustakaan yang di titipkan. ${ }^{13}$

\section{Pengadaan Buku Melalui Terbitan Sendiri}

\section{November 2020}

12 Massofa, 2008. Pengadaan Bahan Pustaka. (http://mussofa.wordpress.com 2009) diakses pada 11

${ }^{13}$ Margill, Rose, Mery and John. Acquistition Management and Collection Development Buinding. Studies in Development and Affective Use Of Library Resource. 1982. 
Perpustakaan bisa juga melakukan inovasi seperti penambahan jumlah koleksinya dengan cara menerbitkan sendiri. Artinya adalah penerbitan lembaga induk (pusat) perpustakaan yang bersangkutan atau unit unit dilingkungannya, sebagai sebuah contoh untuk penerbitan individu oleh perguruan tenggi dapat membuat sebuah laporan tahunan, kemudian buku pedoman, katalog, majalah, laporan penelitian, kumpulan karangan dan lain sebagainya. Sementara penerbit oleh perpustakaan sendiri dapat berupa tambahan koleksi, bibliografi, bulletin, manual dan sebagainya. ${ }^{14}$

Publikasi perpustakaan merupakan sumber yang selalu dapat dipakai untuk hadiah dan tukar menukar bahan pustaka serta untuk sarana promosi perpustakaan. Perpustakaan hendaknya menyimpan semua terbitan lembaga induk dan perpustakaan yang bersangkutan.

\section{Pengadaan Terbitan Berseri}

Pengadaan terbitan berseri mencakup kegiatan seleksi atau pemilihan pengadaan memalui pembelian, tukar-menukar, hadiah, dan penerbitan sendiri oleh perpustakaan. Prosedur pemesanan terbitan berkala adalah setelah dilakukan verifikasi maka pustakawan pengadaan merbitan berkala mempersiapkan kartu pesanan atau draf pesanan dan pemesanan. Pengadaan terbitan berkala melalui pembelian atau berlangganan dapat dilakukan dengan berbagai cara, seperti melanggan langsung ke penerbit di dalam atau di luar negeri, melanggan langsung kepada agen di dalam atau di luar negeri, toko buku, dan sebagainya. Berbagai macam masalah dihadapi pustakawan dalam mengurus langganan terbitan berkala. Pertukaran dengan instansi lain merupakan salah satu sumber dalam pengadaan terbiatan berkala. Terbitan tersebut merupakan sumber yang sangat potensial sebagai bahan purtukaran. Terbitan berkala dapat diperoleh pula sebagai hadiah dari instansi atau institusi berbeda, boleh dari segi permintaan maupun tidak atas permintaan. Oleh karena itu sebuah Perpustakaan yang dijadikan sebagai sebuah pusat penyimpanan semua publikasi yang diterbitkan oleh lembaga induk juga 
merupakan salah satu cara untuk menambah literature atau khasanah koleksi perpustakaan. ${ }^{15}$

\section{Pengadaan Bahan Non Buku}

Pengadaan bahan non buku diperlukan seleksi terlebih dahulu. Dalam melakukan seleksi bahan pustaka tersebut perlu dilakukan evaluasi mana yang baik dari segi isi, maupun fisik bahan pustaka tersebut. Ada beberapa kriteria umum yang perlu dipertimbangkan dalam melakukan seleksi bahan non buku, yaitu kualitas isi, kualitas teknis, kualitas fisik, dan prosedur/distributor. Untuk melakukan seleksi perlu alat bantu seleksi baik yang berfungsi sebagai alat seleksi, dimana terdapat tinjauannya ataupun berfungsi sebagai alat verifikasi dan identifikasi.

Setelah melakukan seleksi berdasarkan kriteria yang telah ditentukan dengan menggunakan alat bantu seleksi, maka langah selanjutnya dalah melakukan penggadaan. Seperti halnya buku dan majalah, pengadaan bahan non buku dapat dilakukan dengan cara pembelian, hadiah, dan pertukaran. Pembelian bahan non buku pada umumnya melalui produsen ataupun distributor. Sistem pesanan ada yang dilakukan dengan sistem approval plan, blanket o.rder, ataupun standing order. Untuk pengadaan flim import harus ada izin terlebih dahulu dari department luar negeri serta lolos dari bahan sensor flim.

Untuk melakukan seleksi bahan non buku, diperlukan pengetahuan tentang bahan non buku, apa yang akan di seleksi, bagaimana ciri-cirinya yang termasuk kedalam ketegori bahan non buku adalah bahan pustaka yang tidak termasuk kedalam defenisi buku, majalah, atau pamphlet dan perlu penanganan secara khusus. Sebagai contoh adalah bahan pandang dengar, bentuk micro, dan sumber elektronik. ${ }^{16}$

\section{Laporan Pengadaan Bahan Pustaka}

Semua kegiatan dalam rangka pengadaan koleksi harus dicatat dan dengan teliti untuk penyusunan laporan. Setiap perpustakaan seharusnya memiliki ketentuan tertulis tentang penyusunan laporan kegiatan perpustakaan secara umum termasuk kegiatan pengadaan koleksi. Laporan pengadaan bahan pustaka meliputi, jumlah pengadaan menurut jenis bahan pustaka, pengadaan menurut sumber dan anggaran

${ }^{15}$ Wartman, William A. Collection Manangement: Background and Princples. (Chicago: American Library Association. 1989). 21.

${ }^{16}$ Elva Rahmah, Testiani Makmur, Kebijakan Sumber Informasi Perpustakaan:Teori Dan Aplikasi.94 
yang digunakan untuk pengadaan bahan pustaka. Bagian pengadaan bahan pustaka tidak semata-mata bertangung jawab atas hal-hal berikut. ${ }^{17}$

a. Pengadaan atau pengembangan koleksi

b. Pemecahan persoalan-persoalan yang muncul dalam pemesanan bahan pustaka

c. Pembuatan rencana pemilihan bahan pustaka yang terus-menerus

d. Pemeriksaan dan mengikuti terus-menerus penerbitan-penerbitan bibliografi

e. Berusaha memperoleh bahan-bahan reproduksi apabila bahan aslinya sudah tidak diperoleh (buku-buku out of print), tetapi sangat diperlukan pemakai

f. Mengadakan hubungan dengan para pedangan atau penyalur buku

g. Mengawasi penerimaan hadiah dan tukar-menukar bahan pustaka

\section{HASIL DAN PEMBAHASAN}

Dinas Perpustakaan dan Arsip Daerah (DPAD) Kabupaten Muaro Jambi berdiri pada tahun 2017 yang merupakan satu-satunya DPAD yang berada di Sengeti yaitu Ibukota Kabupaten Muaro Jambi. Kepala Dinas Perpustakaan dan Arsip Daerah (DPAD) Kabupaten Muaro Jambi bernama Drs. M. Nazman Efendi, Perpustakaan memiliki 23 orang pengewai baik dari pegawai negeri sipil (PNS) maupun honorer. Pada bagian kasi pengolahan perpustakaan yaitu; Yesi Erlian. S.E, Reka Febriyanti, S.H, dan Isyatul Mardiyah, S.Kom. Petugas bagian pengelola bahan pustaka sudah pernah mengikuti Diklat Pustakawan yang di selenggarakan di Perpustakaan Nasional Republik Indonesia pada tahun 2018 di Jakarta dan ikut serta dalam seminar atau pertemuan yang diselenggarakan oleh Dinas Perpustakaan dan Arsip Daerah Provinsi Jambi.

Dinas Perpustakaan dan Arsip Daerah Kabupaten Muaro Jambi memiliki Visi dan Misi yaitu; Visi: "Terwujudnya Dinas Perpustakaan Dan Arsip Daerah Sebagai Pusat Baca Masyarakat Dan Pusat Penyelenggaraan Kearsipan Kabupaten Muaro Jambi” Dan Misi: (1) Mewujudkan Minat Baca Masyarakat (2) Mewujudkan Penyelenggaraan Kearsipan (3) Meningkatkan Pelayanan Kepada Masyarakat (4) Mewujudkan Kinerja yang Akuntabel. Dalam kegiatan sehari-hari, Dinas Perpustakaan dan Arsip Daerah (DPAD) Kabupaten Muaro Jambi selalu berusaha memberikan layanan prima kepada pemustaka yang terdiri dari siswa, peneliti, mahasiswa dan masyarakat Kabupaten Muaro Jambi. salah satu wujud nyata adalah menyediakan beragam koleksi penunjang untuk para pemustaka yang hingga

\footnotetext{
${ }^{17}$ Elva Rahmah, Testiani Makmur, Kebijakan Sumber Informasi Perpustakaan:Teori Dan Aplikasi.95
} 
saat ini berjumlah 9.153 eksemplar. Selain itu, cara untuk meningkatkan kualitas perpustakaan dan mencapai pelayanan prima adalah dengan melaksanakan pengadaan bahan pustaka perpustakaan. Melalui pengadaan bahan pustaka ini, Dinas Perpustakaan dan Arsip Daerah (DPAD) Kabupaten Muaro Jambi dapat meningkatkan jumlah koleksi serta mampu mengetahui apa saja koleksi yang dibutuhkan oleh para pemustaka. Namun, hingga saat ini koleksi yang tersedia semua dalam bentuk koleksi cetak, dan belum ada sama sekali koleksi terbitan berseri serta belum tersedia koleksi elektronik (non buku). Hal ini disebabkan kurangnya pengetahuan pihak pengelola perpustakaan sebelumnya, belum tersedia perangkat teknologi informasi yang memadai, dan Pengadaan dana perpustakaan bahan pustaka tidak berjalan dengan benar terlihat dari kurangnya dana belanja untuk pengadaan bahan pustaka baik dari bahan pustaka terbitan berseri maupun bahan pustaka terekam, kurangnya perhatian mengarah pada pengadaan bahan pustaka sehingga koleksi yang tersedia tidak lengkap, tidak up to date dan tidak terpakai oleh pemustaka.

Berdasarkan hasil observasi dan wawancara dengan pustakawan di Dinas Perpustakaan dan Arsip Daerah (DPAD) Kabupaten Muaro Jambi bahwa selama perpustakaan berdiri dari 2017 hingga sekarang tahun 2020 mereka telah melakukan pengadaan setiap 1 tahun 1 kali jadi total pengadaan yang telah dilakukan selama ini sebanyak 3 kali pengadaan bahan pustaka tercetak. Namun pihak perpustakaan belum pernah melakukan pengadaan bahan pustaka seperti terbitan berseri dan non buku. Menurut mereka koleksi tersebut jarang digunakan oleh pemustaka. Biasanya pustakawan membuat daftar koleksi yang ingin di beli dan berkomunikasi dengan bendahara kemudian memesan kepada agen buku yang berada dari luar Jambi, apabila koleksi yang diinginkan banyak dan berbentuk buku sirkulasi maupun refensi yang tidak ada dijual di Jambi. selanjutnya, apabila bahan pustaka yang di inginkan berjuamlah tidak terlalu banyak, biasayanya pihak perpustakaan membeli koleksi tersebut di toko buku yang tersedia di Jambi seperti Gramedia, Salemba dan lainnya.

Selain pengadaan melalui pembelian, Dinas Perpustakaan dan Arsip Daerah (DPAD) Kabupaten Muaro Jambi juga melakukan pengadaan koleksi nmelalui hadiah, titipan dan melalui bantuan. Pengadaan melalui hadiah biasanya diperoleh dari Polres Muaro Jambi, mahasiswa yang meneliti memberikan hasil karya penelitiannya, dan pihak-pihak lainnya. Selain itu Dinas Perpustakaan dan Arsip Daerah (DPAD) Kabupaten Muaro Jambi jugs menerima hadiah dari Dinas Perpustakaan dan Arsip Daerah (DPAD) Provinsi Jambi hadiah tersebut berupa bahan pustaka tercetak, koleksi buku fiksi dan lainnya. Selanjutnya, pengadaan bahan pustaka melalui titipan bahwa sanya Dinas Perpustakaan dan Arsip 
Daerah (DPAD) Kabupaten Muaro Jambi juga melakukan titipan koleksi atau sistem rolling dengan berbagai perpustakaan sekolah yang ada di Kabupaten Muaro Jambi dan hal ini juga dilakukan dengan pihak Polres Kabupaten Muaro Jambi untuk titipan koleksi yang dimiliki perpustakaan supaya bisa berguna bagi pemakai para Nara Pidana yang ada di Polres Kabupaten Muaro Jambi. Terakhir pengadaan melalui bantuan, bahwasanya Perpustakaan Nasional Republik Indonesis pada tahun 2020 ini telah memberikan bantuan bahan pustaka tercetak kepada sanya Dinas Perpustakaan dan Arsip Daerah (DPAD) Kabupaten Muaro Jambi sebanyak 800 Eksemplar, koleksi yang diberikan sanggat membantu untuk melengkapi koleksi perpustakan.

Berdasarkan hasil wawancara dengan pengelola perpustakaan dapat diketahui kendala yang dihadapi dalam pengadaan bahan pustaka di Dinas Perpustakaan dan Arsip Daerah (DPAD) Kabupaten Muaro Jambi dan pemecahannya.

1. Kurangnya anggaran dana yang tersedia

Pada Dinas Perpustakaan dan Arsip Daerah (DPAD) Kabupaten Muaro Jambi sangat sedikit sekali pemasukan dana dalam pengadaan bahan pustaka perpustakaan tidak berjalan dengan benar terlihat dari kurangnya dana belanja untuk pengadaan bahan pustaka baik dari bahan pustaka terbitan berseri maupun bahan pustaka terekam, kurangnya perhatian mengarah pada pengadaan bahan pustaka sehingga koleksi yang tersedia tidak lengkap, tidak up to date dan tidak terpakai oleh pemustaka.

Seharusnya Dinas Perpustakaan dan Arsip Daerah (DPAD) Kabupaten Muaro Jambi harus mengolah dana dengan baik dengan memperhatikan kebutuhan pengguna agar bahan pustaka yang di beli sesuai dengan user education. Sehingga dana yang dikeluarkan untuk pengadaan bahan pustaka kelelola dengan baik.

2. Kurang perhatian terhadap pengadaan bahan pustaka

Untuk mencapai visi dan misi serta menunjang perpustakaan yang dijadikan sebagai pusat penyelenggaraan kearsipan maka sangat dibutuhkan perhatian dari semua pihak terutama dari pemimpin itu sendiri karena sistem pengadaan bahan pustaka pada Dinas Perpustakaan dan Arsip Daerah (DPAD) Kabupaten Muaro Jambi tidak berjalan dengan lancar.

Semestinya kepala Dinas Perpustakaan dan Arsip Daerah (DPAD) Kabupaten Muaro Jambi harus lebih memperhatikan dan mendengarkan keluh kesah dari bagian pengelola dalam pengadaan bahan pustaka. Hal ini untuk menunjang 
kualitas perpustakaan untuk memiliki koleksi yang up to date, lengkap, dan terpakai oleh pemustaka.

3. Koleksi yang tersedia merupakan bahan pustaka terbitan lama sehingga ketika pengguna menanyakan terbitan terbaru di Dinas Perpustakaan dan Arsip Daerah (DPAD) Kabupaten Muaro Jambi tidak bisa memberikan sesuai dengan permintaan pemustaka.

Seharusnya Dinas Perpustakaan dan Arsip Daerah (DPAD) Kabupaten Muaro Jambi mampu menyediakan koleksi terbitan baru, agar pengadaan bahan pustaka bisa berjalan dengan lancar perlu dipilih bahan pustaka yang akan di koleksi yaitu dengan cara memperhatikan kebutuhan pemustaka.

\section{E. PENUTUP}

\section{Kesimpulan}

Pada penelitian ini dapat ditarik kesimpulan yaitu: (1) Dinas Perpustakaan dan Arsip Daerah Kabupaten Muaro Jambi telah melakukan kegiatan Pengadaan bahan pustaka melalui pembelian dari agen buku, toko buku, hadiah, titipan dan melalui bantuan sebanyak 1 kali setiap tahunnya. (2) Dinas Perpustakaan dan Arsip Daerah Kabupaten Muaro Jambi tidak pernah melakukan pengadaan terbitan berseri, serta bahan non buku (karya rekam) karena menurut mereka bahan pustaka tersebut jarang dibutuhkan oleh pemustaka. (3) Pengadaan dana perpustakaan bahan pustaka tidak berjalan dengan benar terlihat dari kendala yang terjadi yakni kurangnya dana belanja untuk pengadaan bahan pustaka baik dari bahan pustaka yang tercetak maupun noncetak, serta kurangnya perhatian pemimpin yang mengarah pada pengadaan bahan pustaka sehingga koleksi yang tersedia tidak lengkap, tidak up to date dan tidak terpakai oleh pemustaka.

\section{Saran}

Berdasarkan hasil penelitian di atas penulis dapat menarik kesimpulan seperti yang di atas, maka penulis juga memberikan saran kepada Dinas Perpustakaan dan Arsip Daerah Kabupaten Muaro Jambi seperti berikut: (1) pihak perpustakaan sebainnya tetap melakukan pengadaan bahan pustaka kemudian ditambah dengan pengadaan buku secara tukar-menukar dan pengadaan buku melalui terbitan sendiri serta untuk sarana promosi perpustakaan. (2) Dinas Perpustakaan dan Arsip Daerah Kabupaten Muaro Jambi hendaknya tetap malakukan pengadaan koleksi terbitan berseri maupun karya rekam karena dengan koleksi tersebut bisa menambah jumalah koleksi yang tersedia, mewujudkan minat baca masyarakat serta 
menambah khasanah koleksi perpustakaan. (3) Dinas Perpustakaan dan Arsip Daerah Kabupaten Muaro Jambi sebaiknya harus mengolah dana dengan baik dengan memperhatikan kebutuhan-kebutuhan pengguna agar bahan pustaka yang di beli sesuai dengan user education. Hendaknya kepala Dinas Perpustakaan dan Arsip Daerah Kabupaten Muaro Jambi harus memberikan perhatian lebih yang mengarah pada pengadaan bahan pustaka sehingga koleksi yang tersedia nantinya bisa up to date, lengkap, dan bisa terpakai oleh pemustaka.

\section{F. DAFTAR PUSTAKA}

Elva Rahmah, Testiani Makmur, Kebijakan Sumber Informasi Perpustakaan:Teori dan Aplikasi Yogyakarta: Graha Ilmu, 2015.

Sulistyo Basuki, Pengantar Ilmu Perpustakaan. Jakarta: PT. Gramedia Pustaka Utama, 1993.

Darmono, Perpustakaan Sekolah:Pendekarab Aspek Manajemen dan Tata Kerja. Jakarta: Grasindo, 2007.

Soetimah, Perpustakaan Pustakawan Dan Kepustakawanan, Yogyakarta:Kanisius, 1992.

Gusnimar, Delman. Pengadaan Bahan Pustaka Di Perpustakaan Politeknik Pertanian Universitas Andalas Payakumbuh. Jurnal Ilmu Informasi Perpustakaan dan Kearsipan Vol. 1, No. 1, September 2012.

Bafadal, Ibrahim. Pengelolaan Perpustakaan Sekolah. Jakarta: Bumi Aksara. 2009.

Sugiyono, Metode Penelitian Kuantitatif, Kualitatif R \& D (Bandung: Elfabeta, 2007.

Amir Hamzah. Metode Penelitian Kepustakaan (Library Research). Malang: Literasi Nusantara Abadi, 2019.

Massofa, 2008. Pengadaan Bahan Pustaka. (http://mussofa.wordpress.com 2009) diakses tanggal 11 November 2020.

Margill, Rose, Mery and John. Acquistition Management and Collection Development Buinding. Studies in Development and Affective Use Of Library Resource. 1982.

Wartman, William A. Collection Manangement: Background and Princples. Chicago: American Library Association. 1989. 